\title{
NATIONAL TRANSPORTATION POLICY AND THE REGULATION OF MOTOR CARRIERS*
}

Two Federal District Courts recently held that the Interstate Commerce Commission had exceeded its statutory discretion by denying licenses to certain contract motor carrier applicants. ${ }^{1}$ Although an analysis of the Motor Carrier Act and its legislative background does not support the courts' holding that the commission exceeded its statutory discretion, concern for a proper allocation of resources and an economically efficient transportation system may dictate results different from the ones reached by the commission.

Trucking, like other forms of transportation, has traditionally been subject to some degree of extraordinary regulation in the public interest. As with all such regulation, a distinction has been drawn between common and contract carriage. ${ }^{2}$ A common carrier may be defined as one who holds himself out as willing to carry any or specified commodities for all who may choose to employ him $;^{3}$ upon making this offer he becomes legally obligated to serve all shippers at reasonable rates and without discrimination. ${ }^{4} \mathrm{~A}$ contract carrier, on the other hand, is one who does not hold himself out to serve the public ; ${ }^{5}$ he incurs no special legal obligations. At common law, the distinction was relevant primarily in determining whether a carrier was liable in trespass for refusing to transport goods within the scope of his usual business and in deciding what standard of care the carrier owed to prevent the damage of goods in transport. ${ }^{6}$ Under the Federal Motor Carrier Act of 1935, however, the dichotomy

*J-T Transp. Co. v. United States, 185 F. Supp. 838 (W.D. Mo. 1960); Reddish v. United States, 188 F. Supp. 160 (W.D. Ark. 1960).

1. J-T Transp. Co. v. United States, 185 F. Supp. 838 (W.D. Mo. 1960), reversing J-T. Transp. Co., Inc., Extension, 79 M.C.C. 695 (1959), prob. jutris, noted sub. nom. ICC v. J-T Transp. Co., Inc., 365 U.S. 808 (1961) ; Reddish v. United States, 188 F. Supp. 160 (W.D. Ark. 1960), reversing E. L. Reddish Contract Carrier Application, 81 M.C.C. 35 (1959), prob. juris. noted sub. nom. ICC v. Reddish, 365 U.S. 877 (1961).

2. For a fuller discussion of the distinction between these carriers at common law, see Note, Contract Carriage by Common Carriers Under the Shipping Act of 1916, 70 YALE L.J. 1184 (1961).

3. 1 Hutchinson, Carriers $\$ \S 47,49,59$ (3d ed. 1906); 1 Wyman, Public Service Corporations 167-68 (1911).

4. 1 Moore, Carriers 134-41 (2d ed. 1914). The common carrier has to serve all members of the public alike. Thus, he is held to perform a specialized service for others if he has performed a similar service for one shipper. 1 Wyman, Public Service CorporaTroNs 210-14 (1911).

5. 1 Hutchinson, Carriers $\$ 35$ ( $3 \mathrm{~d}$ ed. 1906). Prior to administrative regulation, the contract carrier was not distinguished from private carriage. 1 Wyaran, Public Service Corporations 210 (1911).

6. E.g., Faucher v. Wilson, 68 N.H. 338, 38 Atl. 1002 (1895); Cumberland Tel. \& Tel. Co. v. Morgan's L. \& T. R. Co., 51 La. Ann. 29, 24 So. 803 (1899); Thomas v. National Delivery Ass'n, 24 F. Supp. 171 (W.D. Pa. 1937). The common carrier is held to be an insurer of the safety of goods he carries. 1 MOORE, CARRIERs 3-4 (2d ed. 1914). 
between common and contract carriage has assumed a quite different and further reaching significance.

The Federal Motor Carrier Act ${ }^{7}$ was passed in 1935 largely at the insistence of the railroads, ${ }^{8}$ but with the support of the ICC, ${ }^{9}$ some large trucking companies ${ }^{10}$ and certain states which had unsuccessfully attempted to regulate interstate truckers. ${ }^{11}$ The Act vested in the ICC extensive control over the entry, scope of operations, and rates of both common and contract interstate motor carriers. ${ }^{\mathbf{1 2}}$ To obtain operating authority from the ICC, prospective common carriers were required to prove the "public convenience and necessity" of their operations; ${ }^{13}$ prospective contract carriers had to prove that their operations would be "consistent with the public interest" and national transportation policy. ${ }^{14}$ Furthermore, the ICC was empowered to limit authorization to specified commodities, routes, territory, and so forth. ${ }^{15}$ In addition, the commission was given authority to establish reasonable minimum rates for any given contract carrier ${ }^{16}$ and both reasonable minimum and

7. Part II of the Interstate Commerce Act, $\$ \S 201-27,49$ Stat. 543 (1935), as amended, 49 U.S.C. $\$ \$ 301-27$ (1958).

8. Coordination of Motor Transportation, 182 I.C.C. 263 (1932); Hearings on H.R. 6836 before the House Committee on Interstate and Foreign Commerce, 73d Cong., $2 \mathrm{~d}$ Sess. 210, 238-43, 284-310; 79 Cong. Rec. 12208, 12222 (1935); see also Healy, The Economics of TRANSPORTATION 425-28 (1940). For a general discussion of the motor carrier act, see Wagner, A Legtslattve History of the Motor Carrier Act (1935).

9. Coordination of Motor Transportation, 182 I.C.C. 263 (1932); General Rate Level Investigation, 195 I.C.C. 5, 61, 70-71 (1933).

10. McCollester \& Clark, Federal Motor Carrier Regulation 86 (1935). In general, however, there was little shipper demand or support for federal regulation, partly because of experience with similar state regulation, which had had the effect of raising truckers' rates to the level of the railroads. In his report to Congress on transport regulation in 1934, the Federal Coordinator of Transportation noted the opposition of the National Industrial Traffic League, a substantial organization of industrial shippers, to "any Federal regulation that goes beyond the keeping of records, the filing of reports, and joint arrangements for complete service between railroads and trucks." Federal Coordinator of Transportation, Regulation of Transportation Agencies, S. Doc. No. 152, 73d Cong., 2d Sess. 26 (1934).

11. State regulation of motor carriers began in the twenties, without widespread popular demand. The proponents at that time were the railroads and some large motor carrier firms. HEALY, op. cit. supra note 8 , at 425 . On the background of state legislation, see generally, Harper, Economic Regulation of the Motor TrUCKIng INdUSTRY by the States 26-43 (1959). However this effort was halted as to interstate truckers in 1925 when the court held such legislation unconstitutional as an undue burden on interstate commerce. Buck v. Kuykendall, 267 U.S. 307 (1925); Bush \& Sons Co. v. Maloy, 267 U.S. 317 (1925).

12. Pt. II, $\S \S 201-27,49$ Stat. 543 (1935), as amended, 49 U.S.C. $\$ \S 301-27$ (1958).

13. Pt. II, $\$ 207$ (a), 49 Stat. 551 (1935), as amended, 49 U.S.C. $\$ 307$ (a) (1958).

14. Pt. II, $\$ 209$ (b), 49 Stat. 553 (1935), as amended, 49 U.S.C. $\$ 309$ (b) (1958).

15. Pt. II, $\$ 208$ (a), 49 Stat. 552 (1935), as amended, 49 U.S.C. $\$ 308$ (a) (1958); Pt. II, $\S 209$ (b), 49 Stat. 553 (1935), as amended, 49 U.S.C. $\$ 309$ (b) (1958). (1958).

16. Pt. II, § 218(b) - (c), 49 Stat. 562 (1935), as amended, 49 U.S.C. $\$ 318$ (b)-(c) 
maximum rates for a common carrier. ${ }^{17}$ The rationale for so extensively regulating the trucking industry (in addition to the generalization that transportation has always been subject to special governmental treatment) was the alleged necessity of eliminating "destructive competition between truckers." 18 Such competition, the advocates of regulation argued, had led to serious financial demoralization of carriers, resulting in excess capacity, impaired standards of service, rate wars, abuse of the nation's highways, and failure to observe safety standards. ${ }^{19}$ In addition, the railroad industry argued that since the railroads were subject to strict control by the $\mathrm{ICC}$, it was unfair for their growing competitors, the trucking industry, to escape regulation. ${ }^{20}$

Although contract carriage had traditionally been considered private business not properly subject to governmental regulation, ${ }^{21}$ it was evident that the purposes of the Act could not be effectuated without control of the contract carrier because of his particularly important economic role in the trucking industry. ${ }^{22}$ This problem had not arisen in other modes of transportation, where the contract carrier played an insignificant role. ${ }^{23}$ But the absence of substantial economies of scale in trucking meant that a carrier could profitably conduct restricted operations serving a limited number of shippers. Moreover, one of the primary advantages which trucking had over its competitors was its ability to perform services tailored to the particular needs of shippers ;24 and the contract carrier, since he had a limited number of customers and since he could not be charged with unlawful discrimination, was particularly capable of providing this flexible service. ${ }^{25}$

17. Pt. II, $\S 216,49$ Stat. 558 (1935), as amended, 49 U.S.C. $\S 316$ (1958).

18. E.g., Coordination of Motor Transportation, 182 I.C.C. 263, 362 (1932).

19. Federal Coordinator of Transportation, Regulation of Transportation Agencies, S. Doc. No. 152, 73d Cong., 2d Sess. 5-35 (1934) ; Coordination of Motor Transportation, 182 I.C.C. 263,362 (1932).

20. 182 I.C.C. at 382-92 (1932) ; HEALY, op. cit. supra note 8, at 426-28. "[R] egulation tends to beget further regulation. For if one industry is regulated then it may be urged that its competitors should, in fairness, also be regulated." ATT'y GEN. NAT'z Comar. ANTITRUST KER. 269 (1955).

21. Michigan Public Util. Comm'n v. Duke, 266 U.S. 570 (1925); Smith v. Cahoon, 283 U.S. 553 (1931); see also HARPER, op. cit. supra note 11, at 36.

22. Regulation of Transportation Agencies, op. cit. supra note 19, at 193 (1934); HARrer, op. cit. supra note 11, at 36. See also Brown \& Scott, Regulation of the Contract Motor Carricr Under the Constitution, 44 HaRv. L. Rev. 530, 534 n.13 (1931), citing figures of U.S. Bureau of Public Roads which show that contract carriers were more numerous in the industry at that time than common carriers.

23. The same economic factors that would make an industry a natural monopoly would also make small restricted operations unprofitable. See Pegrum, Public Regulation of Business 529 (1959).

24. Taff, Commarertal Motor Transportation 9-11 (rev. ed. 1955).

25. In fact, the commission believed that the only justification for contract carriage in a national transportation system was its inherent flexibility. Keystone Transp. Co. Contract Carrier Application, 19 M.C.C. 475, 498 (1939); see also Canned Goods in Offcial Territory, 294 I.C.C. $371,379-80$ (1955). 
Since the entry restrictions of the Act were designed to control competition, a control which necessarily includes the allocation of traffic, ${ }^{26}$ Congress should have provided a clear definition of the role of each type of carriage and the relationship between them. The common carrier entry requirement, "public convenience and necessity," 27 had through its long use in railroad regulation acquired a reasonably definite meaning; a common carrier had to show a positive need for his service, or in other words, the inadequacy of existing common carrier services. ${ }^{28}$ Consistency with the public interest and national transportation policy, ${ }^{29}$ the contract carrier entry test, had not, however, been defined through experience. Its use does suggest that some difference in treatment of the two types of carriers was intended, but it does not tell us what the difference was. ${ }^{30}$ Was either type of carrier to be promoted or protected at the expense of the other? More specifically, was the existence of common carrier facilities to be considered in determining whether the proposed service of a contract carrier was "consistent with the public interest," and, if so, was this factor to be decisive? Were the rates of either carrier to be held up to the level of the other? Without adequate directives from Congress, the ICC looked to what it considered the general scheme of the statute and the traditional public significance of the common carrier; it therefore concluded that the "underlying purpose [of the Act] is plainly to promote and protect adequate and efficient common carrier service ... and the regulation of contract carriers is designed and confined with that end in view."31 Also the commission believed that contract carriage had an unfair competitive advantage over common: the contract carrier was not burdened with the costs of terminal and freight handling facilities and of a scheduled dependable service for the public; it could freely select shippers on the basis of volume; and it could offer a more personalized service. ${ }^{32}$

Thus, the commission began a long series of steps designed to limit contract carrier operations that were in competition with common carrier opera-

26. Control over rates was to a lesser degree used for the same purpose. E.g., Pt. II, $\$ 218$ (b)-(c), 49 Stat. 562 (1935), as amended, 49 U.S.C. $\$ 318$ (b)-(c) (1958).

27. Pt. II, § 207 (a), 49 Stat. 551 (1935), as amended, 49 U.S.C. \$ 307(a) (1958).

28. It appeared in the Transportation Act of 1920, $\$ 402,41$ Stat. 477 (1920), 49 U.S.C. $\S 1(18)-(20)$ (1958), and was construed in Texas \& N.O. R.R. v. Northside Belt Ry., 276 U.S. 475 (1928). See Pan American Bus Lines Operation, 1 M.C.C. 190, 202-03 (1936).

29. Pt. II, $\S 209$ (b), 49 Stat. 552 (1935), as amended, 49 U.S.C. $\S 309$ (b) (1958). The statute actually reads "consistent with the public interest and the policy declared in section 202(a)," which was a declaration of national transportation policy. This section was the predecessor to the present declaration. See note preceding 49 U.S.C. $\$ 301$ (1958).

30. It is possible that Congress used different terminology to satisfy previous Supreme Court decisions concerning state carrier regulations which seemed to require a different scheme of regulation for the contract carrier. Compare Smith v. Cahoon, 283 U.S. 553 (1931) with Continental Baking Co. v. Woodring, 286 U.S. 352, 369 (1932).

31. Contracts of Contract Carriers, 1 M.C.C. 628, 629 (1937); cited in Keystone Transp. Co. Contract Carrier Application, 19 M.C.C. 475, 491 (1939).

32. Ibid. 
tors. ${ }^{33}$ The most important of these was the modification of the common law definition of contract carriage to confine its operations more narrowly. ${ }^{34}$ To be a contract carrier one now had to perform "specialized" services, either by providing unusual operations tailored to the requirements of a particular shipper or by dedicating equipment to the exclusive use of a particular shipper. $^{35}$ The degree of specialization required varied directly with the number of shippers served, highly specialized service being required for extensive operations. ${ }^{38}$ The commission used this modified definition to require applicants whose operations would have been considered contract carriage under the earlier definition to apply now as common carriers ${ }^{37}$ it also attempted to limit the expansion of already licensed contract carriers by issuing cease and desist orders to those who freely added contracts to their business, ${ }^{38}$ although the Act expressly protected the right of all carriers to add new shippers. ${ }^{39}$ The rationale for such orders was that extensive operations implied a "holding out."40 As the trucking industry developed and common carriers added to their facilities, they began to offer to the public specialized services ${ }^{41}$ similar

33. For example, the commission required contract operations to be under long term bilateral agreements, although it was by no means clear that this was a requirement of the common law. Contracts of Contract Carriers, 1 M.C.C. 628, 634 (1937) (Commissioner Lee dissenting). Also, the commission ruled that contract carriers are not allowed to "tack" operating authorities. "Tacking" rights is a procedure whereby carriers acquire a broader authority by purchase of another carrier's license. Service of Contract Carriers, 49 M.C.C. 103, 107-08 (1949). Moreover, contract carriers are not allowed to interchange equipment or traffic in furtherance of a through movement beyond the authority of the carrier. Lease and Interchange of Vehicles, 52 M.C.C. 675, 720-21 (1951) ; Luper Transp. Co., 38 M.C.C. 263, 266 (1942). However the contract carrier can forward traffic of the shipper beyond points reached by the contract carrier as long as he acts as the shipper's agent and not as consignor. Holmes Contract Carrier Application, 8 M.C.C. 391, 393 (1938). The commission's ingenuity has also managed to produce the "Keystone restriction," which limits a carrier's authorization to certain classes of shippers rather than specified commodities. Keystone Transp. Co. Contract Carrier Application, 19 M.C.C. 475, 496 (1939).

34. E.g., Slagle Contract Carrier Application, 2 M.C.C. 127 (1937) ; Pregler Extension of Operations, 23 M.C.C. 691, 694-95 (1940); see also Doyle Transfer Co. v. United States, 45 F. Supp. 691 (D.D.C. 1942).

35. E.g., Pregler Extension of Operations, 23 M.C.C. 691, 694-95 (1940) ; Craig Contract Carrier Application, 31 M.C.C. 705, 712 (1941); see also id. at 714 (Commissioner Lee concurring).

36. Transportation Activities of Midwest Transfer Co., 49 M.C.C. 383, 397-401 (1949).

37. Slagle Contract Carrier Application, 2 M.C.C. 127 (1937); cf. Nelson Extension, 66 M.C.C. 3 (1955) ; Great Lakes Forwarding Corp. Extension, 72 M.C.C. 739 (1957) and H.C. Gabler, Inc., 30 U.S.L. WEEK 2074 (ICC July 19, 1961).

38. E.g., Transportation Activities of Midwest Transfer Co., 49 M.C.C. 383 (1949); Motor Ways Tariff Bureau v. Steel Transp. Co., 62 M.C.C. 413 (1954); but see Butcher Contract Carrier Application, 1 M.C.C. 485 (1937).

39. 49 Stat. 552 (1935), as amended, 49 U.S.C. $\$ 309$ (b) (1958).

40. Transportation Activities of Midwest Transfer Co., 49 M.C.C. 383 (1949). See note 4 supra and accompanying text.

41. It was perhaps the strict regulation of rates which led common carriers to turn to service as a competitive device. 
to the contract carriers',42 thereby increasing the overlapping area of operations. The commission not only encouraged this expansion of common carriers into the area of specialized operations, it also protected such carriers from contract carrier competition by strictly construing the contract carriage entry test, "consisten[cy] with the public interest." 43 Although some early ICC decisions suggested that this test placed a lesser burden on the applicant than did the common carrier entry test, "public convenience and necessity," commission policy of equating the two was soon established. ${ }^{45}$ Thus the contract carrier applicant had precisely the same burden as the common carrier applicant; he had to prove that existing common carriers were unable or unwilling to carry the proposed traffic. ${ }^{48}$

This ICC policy of protecting common carriers was seriously undermined by United States $v$. Contract Steel Carriers, Inc., ${ }^{47}$ in which the Supreme Court held that if "specialization" was to be read into the definition of contract carriage, this criterion was satisfied by the hauling of limited types of products under continuous contracts with a relatively small number ( 69 in this case) of shippers throughout a large area. ${ }^{48}$ At the least, the effect of this decision was to reincorporate the common law definition into the statute. ${ }^{40}$ The Court also made it clear that a contract carrier is free to search "aggressively" for new business within the limits of his license. ${ }^{50}$ The decision thus meant that the ICC could no longer limit the expansion of authorized contract carriers. ${ }^{51}$ This holding directly led the ICC to request congressional amend-

42. E.g., Bush Constr. Co. v. Platten, 48 M.C.C. 155, 162 (1948); Overland Freight Lines Extension, 69 M.C.C. 143 (1956) ; Girton Bros. Extension, 69 M.C.C. 229 (1956); Taff, Operating Rights of Motor Carriers 65-66 (1953).

43. E.g., Coastal Motor Lines Contract Carrier Application, 77 M.C.C. 510 (1958); and also cases cited note 42 supra. Cf. B \& F Bus Service Contract Carrier Application, 53 M.C.C. 501, 504-05 (1951).

44. Jason W. House Contract Carrier Application, 1 M.C.C. 725, 735 (1937). Bassetti \& Lawson Contract Carrier Application, 1 M.C.C. 187, 189 (1936) ; T. J. McBroom Contract Carrier Application, 1 M.C.C. 425, 426 (1937); Motor Convoy Contract Carrier Application, 2 M.C.C. 197, 202 (1937) ; cf. Forrest Worm Extension, 32 M.C.C. 641, 644 (1942). But cf. C. \& D. Oil Co. Contract Carrier Application, 1 M.C.C. 329 (1936).

45. Compare John Joseph Norton Common Carrier Application, 1 M.C.C. 114 (1936) with William Heim Cartage Co. Extension, 20 M.C.C. 329, 331-32 (1939). In some cases where the commission refuses the applicant on the basis of "adequacy," it deems unnecessary a determination as to whether the applicant offers common or contract service. Roy D. Yienst Common Carrier Application, 79 M.C.C. 265 (1959).

46. E.g., Willard J. Hibbard Extension of Operations, 47 M.C.C. 311, 314 (1947).

47. 350 U.S. 409 (1956), affirming 128 F. Supp. 25, reversing Motor Ways Tariff Bureau v. Steel Transp. Co., 62 M.C.C. 413 (1954).

48. 350 U.S. at $411-12$.

49. The Court's interpretation may even have gone beyond the common law definition; see dissent of Justice Frankfurter, 350 U.S. at 412 . This view is further developed in Note, 43 CORNELL L.Q. 96 (1957).

50. 350 U.S. 409,412 (1956).

51. See Motor Ways Tariff Bureau v. Steel Transp. Co., 62 M.C.C. 413 (1954). 
ment of the Act. ${ }^{62}$ The resultant amendments in $1957^{53}$ not only enacted the commission's definition of contract carriage ${ }^{54}$ and gave the ICC power to convert established contract carriers who did not fit the new definition into common carriers, ${ }^{55}$ but also authorized the commission to limit prospective contract carrier permits to designated shippers. ${ }^{56}$ Although the legislation was primarily concerned with amending the definition of contract carriage, ${ }^{57} \mathrm{Con}$ gress, at the request of the Contract Carrier Conference, ${ }^{58}$ also amended section 209 (b), which governs the issuance of contract carrier permits, to read:

A permit shall be issued to any qualified applicant ... if it appears ... that the proposed operation ... will be consistent with the public interest and the national transportation policy declared in the Interstate Commerce Act. . . . In determining whether issuance of a permit will be consistent with the public interest and the national transportation policy ... the Commission shall consider [1] the number of shippers to be served by the applicant, [2] the nature of the service proposed, [3] the effect which granting the permit would have upon the services of the protesting carriers and [4] the effect which denying the permit would have upon the applicant and/or its shipper and [5] the changing character of that shipper's requirements. ${ }^{59}$

Although the amendment suggests that in section 209(b) proceedings the commission must consider more than adequacy of common carrier services, the commission held that this broad enumeration of factors was not intended to alter its restrictive entry policy toward contract carriers. ${ }^{60}$ In opposition to this view, two district courts have stated that the amendment did work a substantial change in the law. ${ }^{81}$ In $J-T$ Transport $v$. United States, applicant sought a permit to carry uncrated aircraft assemblies, which, because of their fragile nature, required special handling and facilities. J-T's trucks were equipped with special fixtures and were dedicated to the exclusive use of the

52. 70 I.C.C. AnN. Rep. $162-64$ (1956). (1958).

53. Act of August 22, 1957, 71 Stat. 411-12, 49 U.S.C. $\S 303$ (a) (15), 309(b), 312

54. 71 Stat. 411-12 (1957), 49 U.S.C. $\$ 303$ (a) (15) (1958).

55. 71 Stat. 411-12 (1957), 49 U.S.C. $\$ 312$ (c) (1958). For a discussion of some of the problems raised by this provision, see Note, 107 U. PA. L. REv. 1150 (1959).

56. 71 Stat. 411 (1957), 49 U.S.C. $§ 309$ (b) (1958).

57. See note 88 infra.

58. Surface Transportation-Scope of Authority of ICC, Hearings Before a Subcommittee of the Scnate Conntittee on Interstate and Foreign Commerce, 85th Cong., 1st Sess. 304 (1957) [hereinafter cited as 1957 S. Hearings].

59. 71 Stat. 411-12 (1957), 49 U.S.C. $\$ 309$ (b) (1958) (new provisions in italics).

60. E.g., J-T Transp. Co. Extension, 74 M.C.C. 324 (1958), aff'd on rehearing, 79 M.C.C. 695 (1959).

61. J-T Transp. Co. v. United States, 185 F. Supp. 838 (W.D. Mo. 1960), prob. juris. notcd sub nom. ICC v. J-T Transp. Co., 365 U.S. 808 (1961). Reddish v. United States, $18 S$ F. Supp. 160 (W.D. Ark. 1960), prob. juris. noted sub. nom. ICC v. Reddish, 365 U.S. $S 77$ (1961). The court's reasoning in Reddish rests upon the broad holding and implications of the court in $J-T$ Transport. 
shipper to meet his production schedules. ${ }^{62}$ In Reddish v. United States, applicant sought a permit to transport canned goods in less than truckload shipments for three small shippers to numerous destination points. ${ }^{03}$ Both applications were denied. The advantage of contract carriage over existing common carriage urged by applicant in $J-T$ Transport was the assurance of a readily available and personalized service $;^{64}$ in $R e d d i s h$, the alleged advantage was mainly lower rates. ${ }^{65}$ The commission in both cases found no adverse effect that a denial of the application would work on the shippers. ${ }^{60}$ In both cases the commission held that insufficient proof had been adduced of protestant common carriers' inability to render the same or adequate service to the supporting shippers; ${ }^{67}$ and in Reddish, the commission specifically held that the advantage of lower rates was not one to be considered in entry proceedings. ${ }^{68}$ Furthermore, the commission in both cases found that a grant would adversely affect protesting common carriers, notwithstanding that they had not carried this traffic in the past. ${ }^{69}$ In $J$-T Transport it was explicitly stated that "there is, in effect, a presumption that the services of existing carriers will be adversely affected by a loss of 'potential' traffic. . . ."70

The district courts found that the commission had misconstrued the statutory criteria in several respects. First, it had given insufficient consideration to the "distinct," as opposed to the reasonable, transportation needs of the shippers. ${ }^{71}$ In Reddish, the court held that a request for lower rates was such a distinct need, at least where the rates are based on lower operating costs. ${ }^{72}$ Second, the ICC had erroneously employed a presumption of potential adverse effect on common carriers, whereas, in fact, such an effect would ordinarily not exist if the carriers had not previously carried the traffic. ${ }^{73}$ The courts' criticism of the commission for not making proper findings may seem to be merely a technical evidential dispute, since the commission on remand could consider the various factors but balance them so as still to reach the present result. $^{74}$ But the implications of the courts' broader views on the weight to

62. J-T Transp. Co. Extension, 74 M.C.C. 324 (1958) aff'd on rehearing, 79 M.C.C. 695 (1959).

63. Reddish Contract Carrier Application, 81 M.C.C. (1960).

64. 79 M.C.C. at $696-97$.

65. 81 M.C.C. at 42 . The shipper also desired a direct line service in order to avoid costly delays; however, consideration of the service features would appear to be overshadowed by the issue of rates.

66. 79 M.C.C. at 708 ; 81 M.C.C. at $41-42$.

67. 79 M.C.C. at 705-07.

68. 81 M.C.C. at $42-43$.

69. 81 M.C.C. at $41 ; 79$ M.C.C. at 705 .

70. Ibid.

71. $185 \mathrm{~F}$. Supp. at $850 ; 188 \mathrm{~F}$. Supp. at 167 (quoting $J-T$ Transport).

72. $188 \mathrm{~F}$. Supp. at 167.

73. 185 F. Supp. at $849 ; 188$ F. Supp. at 167.

74. The Supreme Court has generally recognized that the Act gives the commission broad discretion in making decisions involving national transportation policy. ICC v. 
be given to the interest of shippers and contract carriers would seem to indicate that a fundamental difference exists between the commission and the district courts. ${ }^{75}$ The courts expressed the belief that the amendments were intended to establish two forms of motor carrier service entitled to "equal" recognition and that the interests of each are entitled to "impartial consideration" in determining the public interest. ${ }^{76}$ Thus, the courts added, a proper finding of adverse effect on protestants does not "in and of itself justify a denial of the application."77 The courts believed that the commission had in fact continued to apply the "adequacy of existing services test" to contract carrier applicants. ${ }^{78}$ And because the courts believed that the statute intended to make the particular needs of shippers and the ability of contract carriers to fulfill them important factors in the balance, they held that the commission could no longer discount these interests simply by finding that common carrier service was adequate. This was prohibited by the all-inclusive nature of the statutory criteria. ${ }^{79}$

A reading of the vague language of the statute does not logically lead to the construction asserted by the courts. The courts not only denied the validity of the commission's presumption of an adverse effect from the fact of adequate common carrier service, but also implied that "adverse effect" ordinarily refers to an actual loss of profits from a diversion of traffic presently handled.80 But a definition of adverse effect on the services of protesting carriers is not to be found in any part of the statute. By continuing to apply the established policy of giving common carriers all the traffic they can presently handle be-

Parker, 326 U.S. 60 (1944); McLean Trucking Co. v. United States, 321 U.S. 67, 87-88 (1944). It did, in one decision, insist that the commission make explicit its findings for refusing a grant of authority to motor carriers. Schaffer Transp. Co. v. United States, 355 U.S. 83, 90 (1957). However, the only opposition to the application involved was from railroads and thus the close scrutiny of the Court can probably be explained by the congressional policy which instructs the commission to preserve the "inherent advantages" of each mode of transportation. Declaration of National Transportation Policy, note preceding 49 U.S.C. $\$ 301$ (1958). Since railroads and trucks are distinct modes, the Court must perforce take a closer look at the evidence of advantages offered by the applicant and the "adequacy" of existing service in order to insure that the commission carries out this specific congressional policy.

75. The commission has postponed decision on many contract carrier applications pending the outcome of the appeal of the $J-T$ Transport case. Letter from Robert Ginnane, General Counsel for the Interstate Commerce Commission, to the Yale Laze Journal, April 5, 1961, on file in the Yale Law Library. The Common Carrier Conference has indicated that it will seek further legislation if the district court opinion in $J-T$ Transport is sustained. Letter from Roland Rice, Counsel for The Common Carrier Conference, to the Yale Law Journal, March 31, 1961, on file in the Yale Law Library.

76. 185 F. Supp. at 851 . This view is implicit in the decision in Reddish, which expressly approves of the reasoning in J-T Transport. $188 \mathrm{~F}$. Supp. at 165-68.

77. 185 F. Supp. at $849 ; 188$ F. Supp. at 167 (quoting the Court in $J-T$ Transport).

78. See note 46 supra and accompanying text.

79. 185 F. Supp. at 848 ; 188 F. Supp. at 166.

80. 185 F. Supp. at $848 ; 188$ F. Supp. at 165. 
fore new service is authorized, ${ }^{81}$ the commission has implicitly defined adverse effect on protestants as any absolute loss of potential profits, however large or small. ${ }^{82}$ This definition does not seem to be clearly unreasonable, because adverse effect may refer to potential as well as present adverse effect; it is at least arguable that a carrier's services are affected by unpredictable future traffic changes which may create a need for additional traffic, ${ }^{83}$ even if he has no present need. ${ }^{84}$ Moreover, since the term is not defined in the Act, the definition one chooses of adverse effect would seem to be a matter of transportation policy, not statutory construction, and therefore better left to the commission than to the courts; ${ }^{85}$ thus, the indulgence of a presumption and the absence of detailed findings on the issue of adverse effect would not seem to be an abuse of discretion, unless the legislative background of section 209 (b) demands a more specific meaning of adverse effect or indicates an intended change in traditional ICC policy. Consideration of the effect on the shipper in the cases was equated by the courts with the consideration of his distinct transportation needs. ${ }^{86}$ But the only mention of distinct needs is found, not in section 209(b), but in the amended definition of contract carriage which refers to such carriage as a specialized service designed to fulfill the "distinct" needs of shippers. ${ }^{87}$ Since this amendment was clearly intended to restrict contract trucking operations in the interests of common carriers, this provision should not be considered a mandate to the commission to fulfill the particular needs of shippers. ${ }^{88}$ Similar criticism can be made of the courts' broader holdings in respect to the increased importance of the shipper's interests and the role of contract carriers vis-à-vis common carriers; such policies cannot be culled from a statute which merely instructs the commission to consider the groups affected by its decision.

81. E.g., C. \& D. Oil Co. Contract Carrier Application, 1 M.C.C. 329, 332 (1936). Forrest Worm and Fred Worm Extension of Operation, 32 M.C.C. 641 (1942) ; Coastal Motor Lines Contract Carrier Application, 77 M.C.C. 510, 513 (1958).

82. See B \& F Bus Serv. Inc., Contract Carrier Application, 53 M.C.C. 501, 504-05 (1951). If this thesis were carried to its logical conclusion, it would require that the ICC refuse a grant in every case, regardless of protestant carrier's present ability, since he might at some future date be able to handle the traffic. But this would leave shippers without any present service, and apparently the ICC is not willing to go that far.

83. Cf. Meyer, Peck, Stenason \& Z INDUSTRIES 9 (1959).

84. How often this would be true is in itself a matter of transportation judgment and policy.

85. See note 109 infra and accompanying text.

86. 185 F. Supp. at $850 ; 188$ F. Supp. at 165 .

87. 71 Stat. 411 (1957), 49 U.S.C. $\$ 303$ (a) (15) (1958).

88. S. REP. No. 703, 85th Cong., 1st Sess. 2 (1957) ; H.R. REP. No. 970, 85th Cong., 1st Sess. 1-5 (1957).

The adoption of the administrative definition of contract carriage was clearly in response to the court's broad definition in Contract Steel Carriers $v$. United States, see text at note 47 supra, and was intended to confine contract operations to a more limited area, but there is no indication that Congress was, at the same time, attempting to increase their importance in that area. 
Thus support for the court's views must be found, if at all, in the legislative history. In enacting the 1957 amendments, Congress was primarily concerned with the difficulty of distinguishing between contract and common carriage and the consequent expansion of contract carriers. ${ }^{89}$ The general purpose of the amendments, as stated to Congress by the Senate Committee, was to limit the activities of contract carriers in order to promote and protect a strong system of common carriage $; 0$ such legislation had been recently recommended in the influential transportation study done by the Department of Commerce. ${ }^{91}$ There was little discussion of the present section 209(b) at the legislative hearings. The Contract Carrier Conference, ${ }^{92}$ in proposing this section to the ICC ${ }^{83}$ and Congress, presented it as one involving no radical departure from previous policy: "We do not believe that this amendment would make it any easier for our contract carriers to obtain new authority. ... All it would do would be to require the Commission to give consideration to factors which, in our opinion, are important to the public interest. ..."95 Since the opinions

89. H.R. REP. No. 970, op. cit supra note 88, at 1-5; S. REP. No. 703, op. cit. supra note 88 at 1-4. Almost all of the ICC proposals were adopted. 70 I.C.C. ANn. ReP. 162 (1956).

90. 103 Cong. REc. 14035-36 (1957) (remarks of Senator Smathers); S. REP. No. 703, op. cit. stipra note 88 at 7 .

91. Report of the Presidential Advisory Committee on Transport Policy and Organization, Revision of Federal Transportation Policy 1-7 (1955) (Weeks Report). In its letter of transmittal to the President, the Advisory Committee recommended that the definition of contract carriage be amended in order to "assure the maintenance of a modernized and financially strong system of common carrier transportation. . . " Cited in 1957 S. Hearings 197. Legislation to implement the recommendations was initiated in the 84th Congress. Digest, Analysis, and Index of Testimony of the Hearings Before a Subcommittee af the H. Committee an Interstate and Foreign Commerce, 84th Cong., 2d Sess. iii-v. The Weeks Report, however, fails to explain the inconsistency between advocating greater reliance on competitive forces in the transportation industry and recommending further regulation of contract and private carriers to protect common carriers from competition. See Meyer, Peck, Stenason \& Z wick, Competition in the Transportation Industries 271 (1959).

92. The Conference is a voluntary association which acts as a pressure group for contract carriers.

93. A similar proposal was made to the ICC in 1954. Recommendations Re Legislation-Motor Contract Carriers, Ex Parte No. MC-46, cited in ICC Administration of the Motor Carrier Act, Hearings Before the S. Select Committee on Small Business, 84th Cong., 1st Sess. 411-17 (1955).

94. 1957 S. Hearings 299-300, 304.

95. The statement read in its entirety: “. .'We do not believe that this amendment would make it any easier for our contract carriers to obtain new authority, except in those circumstances where the proposed service is a substitute for private carriage. . . ." "Except in those circumstances" referred to an additional proposal which stated that "a finding by the Commission that the applicant proposes to assign vehicles to a particular shipper for the performance of a service which the supporting shipper could or does perform with its own vehicles practically, and that such service would not adversely affect existing carriers, shall raise a rebuttable presumption that the proposed service is consistent with the public interest ... even though the applicant is serving more than 15 shippers under contract." 1957 S. Hearings 304. However, this additional proposal was not passed. 
of the district courts implied that the commission could never deny a permit in the absence of a substantial adverse effect under section 209 (b) it seems that their view of the statute is more favorable to contract carriers than that expressed in the Contract Carrier Conference proposal. ${ }^{96}$ More important than the Conference's statement is the fact that the ICC offered no objection to the provision. ${ }^{97}$ In fact, all interested parties, including the railroads and motor common carrier association, approved of the additional language without comment and Congress referred to it as "more helpful standards than are contained in the present law."98 In view of the statements of the Conference, the lack of discussion at the hearings, and the facile acquiescence of the ICC at the time of enactment, apparently no one believed that section 209 (b) was making any substantial changes in the commission's entry policy.

In reaching their conclusions, the courts were primarily influenced by a showing that Congress had rejected the ICC's proposals ${ }^{90}$ which would have defined contract carriage as a specialized service "not provided by common carriage" and would have required applicants to prove that "existing common carriers were unwilling or unable to provide the type of service for which a need has been shown" before a permit could be issued. ${ }^{100}$ These proposals had caused a great deal of controversy at the hearings and were deleted from the bill before passage. But the principal reasons given at the hearings for the rejection of these provisions do not indicate dissatisfaction with past ICC entry standards for contract carriers. The main objection to the inclusion of "not provided by common carriage" in the definition of contract carriage was that it would jeopardize the established business of numerous contract carriers by making their status depend on a changing circumstance, the presence of common carrier service. ${ }^{101}$ Moreover, it was feared that such a definition, combined with the mandatory conversion of contract carriers who no longer met the revised definition, would present serious constitutional questions; ${ }^{102}$ for the Supreme Court had previously held certain state legislation unconstitutional on the ground that contract carriers could not be converted to common carriers by legislative fiat. ${ }^{103}$ The requirement of proving that common

96. 185 F. Supp. at $848-49 ; 188$ F. Supp. at 166-67.

97. S. Rep. No. 703, op. cit. supra note 88 at 4, 6. 103 Cong. Rec. 14035 (1957) (remarks of Senator Smathers).

98. 103 Cong. REC. at 14036.

99. 185 F. Supp. at $843-44 ; 188$ F. Supp. at 165-66.

100. ICC Legislative Recommendation No. 6, 70 ICC ANN. Rep. 162-63 (1956); 1957 S. Hearings 6.

101. S. Rep. No. 703, op. cit. supra note 88, at 5-6; 1957 S. Hearings 193, 202-04, 295, 301-04.

102. 1957 S. Hearings 50-52, 301-04. Cf. id. at 205-06.

103. Michigan Pub. Util. Comm'n v. Duke, 266 U.S. 570 (1925); Frost \& Frost Trucking Co. v. Railroad Comm'n, 271 U.S. 583 (1926). Federal regulation of the contract carrier, although questioned by some writers, has never been challenged on constitutional grounds. Brown and Scott, Regulation of the Contract Motor Carrier Under the Constitution, 44 Harv. L. Rev. 530 (1931), McColtester \& Clark, FederaI Motor 
carriers were unable or unwilling to provide the proposed service was deleted from section 209 (b) because the committee felt that a positive showing of the inability or unwillingness of other carriers would impose a very difficult burden of proof on applicants. ${ }^{104}$ Furthermore, its inclusion would severely restrict those contract carriers applying for extensions of their authority to serve a shipper's increased or changing needs. ${ }^{105}$ Such applications, which supplement the existing rights of carriers, are often granted even though there is adequate common carrier service in the area. ${ }^{106}$

Thus, while there is logical merit in the courts' assumption that since a statute was passed and since it was passed with the purpose of placating contract carriers, it must make some change in the law, no evidence of what this change was appears in the statutory language or its background. Since the ICC prior to the amendment had virtually complete freedom in deciding entry proceedings in accordance with its view of transportation policy, one is led by this lack of evidence to conclude that although Congress did set up some sort of vague criteria, it has in fact left the entire question of goals and standards to the ICC. ${ }^{107}$ While one may question the wisdom of such a broad delegation of power to the ICC to resolve a recurrent situation permeated with sharp conflicts of interest, ${ }^{108}$ it does indicate that the commission's construction should not be considered an abuse of discretion. And since the application of the statute to any particular set of facts involves broad policy questions, a

Carrier Regulation 187-98 (1935). Objections based on the notion that it is not a business "affected with a public interest" would not seem to be valid today. Cf. Nebbia v. New York, 291 U.S. 502 (1934). And see dissent of Justice Black in United States v. Champlin Ref. Co., 341 U.S. 290 (1951), in which he referred to a constitutional challenge alleging that Congress could not force oil carrying pipe lines to serve as common carriers as "frivolous." Id. at 313.

The concern with constitutionality at the hearings ignores the fact that some contract carriers whose operations were legitimate under the traditional definition of contract carriage are being forced to convert solely because of the revised legislative definition.

104. S. REP. No. 703, op. cit. supra note 88, at 4-6, 1957 S. Hearings 300, 303; 103 Cong. Rec. 14035 (1957) (remarks of Senator Smathers).

While rejection of this provision thus does not indicate a desire to prohibit consideration of common carrier adequacy, it does suggest that the commission may not place a strict burden of proof on the applicant. The courts asserted in the principal cases that this had in fact been done. However, while the commission does speak in terms of burden of proof, the record shows substantial evidence of protestant's willingness and ability to carry the proposed traffic.

105. S. REP. No. 703, op. cit. supra note 88, at 4-5; 1957 S. Hearings 303.

106. E.g., Willis Shaw and Ellis Bogan Contract Carrier Application, 72 M.C.C. 275 (1957) ; Dan's Motor Lines, Inc., Extension-Soap Products, 73 M.C.C. 486 (1957); cf. Sidney B. Staley Extension, 52 M.C.C. 253, 259 (1950).

107. Although there is a congressional declaration of national transportation policy, its sweeping and often inconsistent goals do not aid the court or commission in deciding any cases; it may seemingly furnish authority for any positions they desire to reach. See note preceding 49 U.S.C. $\$ 301$ (1958).

108. See 1 Davis, Adarinistrative Law Treatise 88 (1958). 
court should substitute its view for that of the administrative agency only when the latter has clearly abused its discretion. ${ }^{109}$

Although the commission's actions did not exceed its statutory discretion, this is not to say that these actions reflect a sound transportation policy. The commission, in licensing proceedings, consistently refuses to consider both the applicant's cost of operation and rates. ${ }^{110}$ Moreover, many service advantages which can be shown to represent cost savings to shippers are ignored on the ground that common carrier service is still "adequate."111 But unless recognition of lower operating costs and savings to shippers would seriously harm the public interest, these factors are obviously worth preserving in any national transportation policy. If it is assumed that the transportation needs of the economy are best met with a minimum expenditure of economic resources and that an optimum allocation of resources occurs when the price of each commodity equals the minimum cost to society of producing the additional unit of that commodity, then ignoring these factors results in a misallocation of resources. ${ }^{112}$ The amount of resources devoted to the movement of the goods in question is more than the minimum necessary, in that the shipper is prevented from using the carrier who can provide the particular service

109. Arguably, courts can and should exercise a broad review function because the questions involved in the decisions are technically "legal" ones- there being no significant disagreement over the facts-and thus issues on which the courts are competent, and indeed, obliged, to substitute their judgment for that of the commission. The Court, however, has taken a pragmatic approach in classifying questions as law or fact, rather than an abstract analytical view of the law-fact dichotomy. Compare American Trucking Ass'n v. United States, 344 U.S. 298 (1953) and Board of Trade v. United States, 314 U.S. 534 (1942) with Mitchell v. United States, 313 U.S. 80 (1941). Thus, the classification is based primarily upon a consideration of the comparative qualifications of the court or agency to decide the particular issue before them. See Driscoll v. Edison Light \& Power Co., 307 U.S. 104,122 (1939) (concurring opinion). The question in the principal cases, whether in a regulated industry the policy of controlled competition should be strengthened or weakened, is clearly a matter within the specialized field of the ICC. Moreover, the background of a long standing policy not explicitly or implicitly disapproved by Congress would also seem to lend authoritative weight to the commission's interpretation. See, e.g., Mazer v. Stein, 347 U.S. 201 (1954). For a general discussion of the problems involved in judicial review of administrative decisions, see generally 4 Davis, Administrative Law Treatrse $\$ \$ 30.01-.14$ (1958).

110. E.g., General Transp. \& Storage Co. Extension of Operations, 28 M.C.C. 453, 455 (1941) ; Lowther Trucking Co. Extension, 74 M.C.C. 603, 608 (1958); Jasper \& Chicago Motor Express Inc., 69 M.C.C. 224 (1956) ; Hillman L. Melton Contract Carrier Application, 49 M.C.C. 59 (1949).

111. E.g., Jay Logan Contract Carrier Application, 73 M.C.C. 177 (1957), Kilmer Transp. Co. Extension, 53 M.C.C. 561 (1951) ; E.L. Reddish Contract Carrier Application, 81 M.C.C. 35 (1959); but see William Edward Leary Extension, 81 M.C.C. 553 (1959). Also compare the commission's statement that the success of the contract carrier in serving the needs of the canning industry is due to its ability to fulfill requirements not ordinarily met by common carrier service. Canned Goods in Official Territory, 294 I.C.C. 371, 380 (1955).

112. Pegrum, Public Regulation of Business 5-14 (1959); National Resources Planning Board, Transportation and National Poltcy 83-86 (1942). 
desired, at the lowest cost. The commission believes that an entry policy which takes account of cost factors would promote instability in the trucking industry and would impair common carrier services, which are assumed to be of special importance to the public; it is thus willing to sacrifice economic advantages of contract carriage in the interests of a stable common carrier system.

The commission's practice of favoring common carriage is most justifiable in cases where a granting of the application will have an adverse effect on the economic efficiency of the protesting common carrier, that is, where it will raise the cost of his other transportation operations. ${ }^{113}$ Allocating the traffic to the common carrier in this situation will result in a more efficient use of the carrier's resources. If the consequent savings are expressed in lower rates, the economic benefit will accrue to the shippers whom he serves, who may be numerous. However, an adverse effect on economic efficiency does not necessarily follow from a loss of either past or potential traffic. Such an effect depends on the relationship of the proposed traffic to the carrier's other operations. He may need this traffic to avoid empty backhaul mileage or unutilized equipment; otherwise additional traffic will not lower the carrier's costs, since there are no substantial economies of scale in the trucking industry. ${ }^{114}$ Thus, the ICC's policy of indiscriminately according existing common carriers all the traffic they wish to handle often cannot be justified in terms of economic efficiency.

It is true, however, that consideration of rate and service advantages in entry proceedings would diminish the relative role of common carriage in the industry and would result in future diversion of common carrier traffic unless the contract carrier applicant were strictly limited to designated shippers;115 but considerations of the reasons why common carriers cannot compete may lead one to ask whether these consequences are undesirable. The ICC believes that the common carrier, in competing with contract carriage, is handicapped by its public service obligations particularly for assured high volume traffic. These obligations apparently refer to the added insurance costs which cover the common carrier's stricter liability, and the additional costs incurred in maintaining reserve equipment to meet the varying demands of the public, the unprofitable runs necessitated by some overriding public interest, and the

113. At times the ICC has recognized adverse effect in these terms. For example, the relationship between tonnage needed for backhaul loads and efficiency of operations has been held to be a sufficient ground for refusal. William Edward Leary Extension, 74 M.C.C. 361,363 (1958). However, the commission has generally assumed that diversion of traffic results in an adverse effect. E.g., John L. Guex Extension, 67 M.C.C. 224 (1956) ; Jay Logan Contract Carrier Application, 73 M.C.C. 177 (1957).

114. Pegruar, Public Regulation of Business 529-30 (1959); Meyer, Peck, StenaSON \& Zwick, Competitron in the Transportation InDustries 9497 (1959). For a discussion of motor carrier costs, see Roberts, Some Aspects of Motor Carrier Costs: Firm Sise, Efficiency and Financial Health, 32 LAND Econ. 228 (1956).

115. The commission has this power under the amended statute. 71 Stat. 411 (1957), 49 U.S.C. \& 309 (b) (1958). 
terminal facilities required to accommodate shipments of variable sizes. ${ }^{110}$ The extent of excess capacity maintained to meet possible shipping demands is not known, but the ease with which equipment can be obtained to carry additional traffic indicates that this should not be a significant expense. ${ }^{117}$ In addition, the common carrier is not obligated to meet unforeseeable demands upon his service. ${ }^{118}$ More important, these costs resulting from inability accurately to predict operations should not be allotted to assured high-volume traffic and thus should not prevent common carriers from competing with contract carriers on such operations. Similarly, the extent of unprofitable operations conducted by common carriers because of some overriding public interest ${ }^{110}$ is not known; but the absence of numerous service enforcement cases before the ICC suggests that the number of these operations is minimal. ${ }^{120}$ It is also said that the common carrier cannot compete with contract carriage on high volume traffic because he is obligated to accept small as well as large shipments and must therefore maintain terminal facilities. The answer again is that high volume shipments should not bear these costs because they do not use terminal facilities; these costs should be allocated to those smaller shipments which require the use of such facilities. It is true that the added insurance costs of the common carrier would tend to make his operating costs somewhat higher than those of the contract carrier for the same shipment; from the point of view of the shipper, however, the costs would probably be the same, since when the carrier is not strictly liable, the shipper must purchase insurance or bear the risk of loss. Such insurance costs should not therefore place the common carrier at a competitive disadvantage.

While the commission's reasons are of questionable validity, there is substantial evidence that common carriers do face a serious but different problem. In its desire to protect existing common carriers, the commission has niggardly granted operating authority to carrier applicants, placing narrow restrictions upon the commodities, the routes used, the origin, intermediate, and destination points served, and the sizes of shipments transported. ${ }^{121}$

116. Contracts of Contract Carriers, 1 M.C.C. 628 (1937); Kerpdare Transp. Co. Contract Carrier Application, 19 M.C.C. 475, 491 (1939); also see Spurr, The Case For The Common Carrier in Trucking, 24 J. LaNd \& P.U. Econ. 253 (1948).

117. Wirliams, The Regulation of Rati-Motor Rate Competition 9 (1958). Although the units are obviously extremely mobile and relatively inexpensive, and may be obtained by purchase or lease, the commission has somewhat hampered the fluid interchange of equipment by imposing a minimum of 30 days for leases and prohibiting a carrier from substituting another's service for his own. See Charles B. Greer, Jr., Broker Application, 23 M.C.C. 417 (1940) ; American Trucking Ass'ns v. United States, 344 U.S. 298 (1953), and see dissent $i d$. at 328-33.

118. 1 MOORE, CARRIERs $139-41$ (2d ed. 1914).

119. It would not seem that there are any unprofitable operations which are required by an overriding public interest, except service to rural areas and passenger service.

120. The few decisions found concern bus service rather than trucking. E.g., Penn Greyhound, Inc. v. American Bus Lines, Inc., 52 M.C.C. 117 (1950).

121. Special Study Group on Tranportation Policies in the United States, Preliminary Draft of a Report on National Transportation Policy, 87th Cong., 1st Sess. 70, 160, 547-52 
These limitations increase operating costs by preventing many carriers from soliciting needed backhaul traffic, from fully utilizing their equipment daily, and from using the most direct and economical routes. ${ }^{122}$ Moreover, the narrow interpretation of grandfather rights ${ }^{123}$ - statutory rights which assure operating authority to a carrier to the extent of his bona fide operations in 1935-and the restrictions which carriers have thereafter placed upon themselves in their applications-restrictions which were based upon the carrier's conception of a profitable operation at the time of application-have frozen the operating pattern of many carriers regardless of changed market conditions for traffic. ${ }^{124}$ Thus, it is not surprising that what was an efficient operation many years ago is not efficient today, because of the construction of new highways or the shift in industries from one locality to another. The ICC's protective policy toward common carriage serves only to perpetuate and increase these economic inefficiencies.

While the public service costs discussed by the ICC do not necessarily make common carriage noncompetitive with contract carriage, they have in fact handicapped the common carrier; this, however, results from the peculiar nature of the common carrier rate structure. With the establishment of regulation in 1935, common carriers were required to file tariffs with the ICC "and it was easier to adopt the pattern of railroad rates than to construct an entirely independent structure. . .."125 Such rates are largely determined by value of

(Comm. print 1961) [hereinafter cited as NAT'z Transp. Policy REP.] ; Board of Investigation and Research, $A$ Report on Federal Regulatory Restrictions Upon Motor and Water Carriers, S. Doc. No. 78, 79th Cong., 1st Sess. 25-36, $44-74$ (1945) ; Hearings on the Administration of the Motor Carrier Act By the Interstate Commerce Commission, As It Affects Small Truckers and Shippers Before the Senate Select Committee on Small Business, 84th Cong., 1st Sess. 243-45 (1955). The Commerce Department has recently recommended elimination of many of these restrictions. United States Departarent of Comaierce, Federal Transfortation Policy and Program 15 (1960).

122. Board of Investigation and Research, $A$ Report on Federal Regulatory Restrictions Upon Motor and Water Carriers, S. Doc. No. 78, 79th Cong., 1st Sess. 44-74, 208-27 (1945). See also authorities cited at note 121 supra.

123. The Act provides that the commission shall issue a certificate to a common carrier and a permit to a contract carrier who shows that he was in bona fide operation as a common or contract carrier on June 1, 1935, and continuously thereafter. 49 Stat. 551, 553 (1935), 49 U.S.C. $\$ \$ 306(a), 309$ (1958). This provision was to protect businesses established before the enactment of entry regulations. Common or contract carrier applicants who do not come under the "grandfather" clause must, of course, prove "public convenience and necessity" or "consistency with the public interest." TAFF, OpERAting RIgEts of Motor Carriers 31-35 (1953).

124. The ICC has no authority to alter a certificate once issued except for a willful violation of the Act. Smith Bros., 33 M.C.C. 465 (1942). Moreover, no records are kept of the restrictions imposed and their relationship to the changing patterns of traffic in a particular area. This would probably be administratively unfeasible. Hearings on the Administration of the Motor Carrier Act By the Interstate Commerce Commission, As It Affects Sinall Truckers and Shippers, supra note 121, at 337-39.

125. Lockinn, Economincs of Transportation 686 (3d ed. 1947). Moreover, the adoption of such a rate structure had the advantage of matching the rates of the trucker's 
service pricing, which bases rates, not primarily on costs, but roughly on the ability of commodities and areas to bear the charges; the value of the commodity is used as an indication of the elasticity of demand for the particular mode of transportation, and higher rates, unrelated to differences in cost, are assigned to high value commodities. ${ }^{126}$ Value of service pricing might be economically justifiable in industries with high fixed costs. Since direct costs are a small percentage of fixed costs, a carrier can establish prices for low value commodities at substantially below total costs without placing any additional burden on other traffic. In fact, any amount charged which exceeds direct costs will go to overhead; it will thus diminish the cost borne by other traffic. ${ }^{127}$ In trucking, however, where the costs are nearly all variable, ${ }^{128}$ such a rate structure becomes a method of requiring some shippers to subsidize the low priced movement of others. ${ }^{129}$ This results in a distorted allocation of resources, for the price of each commodity will not accurately reflect the costs incurred in producing and marketing it. ${ }^{130}$ The disproportion between the rates and costs of common carriers has been increased by the use of broad average cost factors, when costs are considered at all $;^{\mathbf{1 3 1}}$ such factors ignore the lower cost of carrying special classes of traffic which offer an opportunity for better utilization of capacity. Even when an individual carrier wishes to deviate from this structure, he is largely prevented from so doing by pressure from the rate bureaus-voluntary organizations of carriers, which establish rates for their members. ${ }^{132}$ In contrast to common carriage rates, those charged by contract

principal competitor, the railroad, on many commodities and along with the service advantages of trucking, enabled motor carriers to divert substantial traffic from the railroads. United States Department of Commerce, Federal Transportation Policy and ProGRAM 4 (1960). For a discussion of the effects of this rate structure on railroads, see Williams, Some Aspects of the Problem of Intercarrier Competition, 11 VAND. L. Rev. 971, 980-85 (1958) and note 138 infra.

126. Meyers, Peck, Stenason \& Zwick, The Econonics of Conspetition in the Transportation INDUSTRIES 173 (1959).

127. Locklin states that preferential rates do not burden other traffic if two conditions are fulfilled: "These are that the rates must more than cover the direct costs; and (2) that the traffic will not move at higher rates." LockLIN, op. cit. supra note 125 , at 155 .

128. Fixed costs are those which do not vary with changes in output; conversely variable costs are those which do. Samiuelson, Econonics 443 (3d ed. 1955). The ICC believes that at least $90 \%$ of the total costs are variable for common motor carriers. ICC Bureau of Accounts and Cost Finding, Explanation of the Development of Motor Carricr Costs With a Statement of Their Significance 81 (1958). One authority has indicated that this study substantially underestimates the total amount of variable costs. MEYers, PEck, STENASON \& ZWICE, op. cit. supra note 126 , at 87-88.

129. Wilson, Effects of Value-of-Service Pricing Upon Motor Cammon Carriers, 63 J. PoL. EcoN. 337, 338-342 (1955).

130. Natronal Resources Planning Board, Transportation and National Policy 85 (1942).

131. E.g., Central Territory Motor Carrier Rates, 8 M.C.C. 233 (1938); Dodge \& Carll, The Influence of Proprietary Trucking Upon Minimum Rate Policy in Califormia, 11 VANd. L. Rev. 1109, 1120-21 (1958).

132. If a carrier files a proposed rate change, objection is often filed with the ICC by motor carrier associations. The proponent then has the often difficult burden of proving 
carriage are largely a matter of bargaining between the shipper and carrier, and since ample alternatives are available, these rates are likely to conform closely to the costs of providing the service. ${ }^{133}$ While the commission has approved if not encouraged the value of service rate structure for common carriers, ${ }^{134}$ it has not held contract carrier rates up to the level of common carrier rates; instead, it has generally approved lower contract rates when they are justified by actual costs. ${ }^{135}$ It follows, of course, that contract carriers focus on the traffic most discriminated against by common carriage. The recognition of lower contract carrier rates would result in a further erosion of high value traffic away from common carriers. ${ }^{136}$ To the extent that an economically efficient common carrier system is considered desirable, the present common carrier rate structure is therefore unjustifiable ${ }^{137}$ and not in the public interest. ${ }^{138}$ It is true that value of service pricing may aid certain ship-

that his reduction is reasonable. In $45 \%$ of the cases where rate changes have been contested, the application has been withdrawn prior to a hearing. Traffic World 20-22 (January 28, 1956).

133. See New England Rate Bureau, Inc. v. Lewers \& McCauley, 30 M.C.C. 651 (1941); Wilson, Effects of Value-of-Service Pricing upon Motor Common Carriers, 63 J. PoL. Econ. 337, 338-342 (1955).

134. E.g., New England Motor Carrier Rates, 8 M.C.C. 287, 321 (1938), in which the commission rejected an attempt to make classifications based upon cost-of-service factors, since they did not correspond to the railroad classifications.

135. E.g., New England Motor Rate Bureau, Inc. v. Lewers \& McCauley, 30 M.C.C. 651 (1941). The commission's view in determining contract carrier rates is puzzling to say the least, since $\$ 218$ is the only provision in the Act which expressly requires consideration of common carriers in determining a matter concerning contract carriers.

136. For a good discussion of diversion of "cream" traffic from common carriers, see Wilson, Effects of Value-of-Service Pricing Upon Motor Common Carriers, 63 J. PoL. Econ. 337 (1955).

137. Of course, some shippers and areas presently benefitted by the rate structure would be injured. However, the adjustment of the rate structure under competitive pressure of contract carriage would seem to be as gradual a way as any to introduce this needed change. But of. United States Departarent of Commerce, Frederal Transportation Policy and Program 17 (1960).

138. Although a change in the motor common carrier rate structure is clearly related to the railroads, consideration of railroad-truck rate relationships is beyond the scope of this Note.

Omission of this aspect of the problem would not seem to impair the conclusions herein reached. First of all, Congress has expressly stated in its declaration of national transportation policy, 54 Stat. 899 (1940), see note preceding 49 U.S.C. $\$ 301$ (1958), that the inherent advantages of each mode of transportation are to be fostered and preserved. This provision has been construed to mean that motor carrier authorization may not be refused on the ground that existing rail service is adequate. Shaffer Transp. Co. v. United States, 355 U.S. 83 (1957). And in the 1958 Amendment to the Interstate Commerce Act it is stated that "Rates of a carrier shall not be held up to a particular level to protect the traffic of any other mode of transportation, giving due consideration to the objectives of the national transportation policy declared in this Act." 72 Stat. 572 (1958), 49 U.S.C. § 15 (a) (3) (1958). Despite the rather vague qualification, this would seem to suggest that motor carrier rates should be established independently of railroad rates. See Transportation Act of 1958, S. Rep. No. 1647, 85th Cong., 2d Sess. 1-5 (1958) and Paint and Related 
pers, commodities, or geographical areas; but when the commission permits or encourages such subsidizations, it is making judgments of a highly political nature for which it is not as well suited as Congress. Neither the Act nor its introductory declaration of policy indicates that regulation was designed to subsidize any particular commodities or geographical areas.

Even if the common carriage rates and operating restrictions were revised so that common carriers could compete with contract carriage, greater consideration of the advantages of contract carrier service to the shippers would place common carriers in a less secure position than they presently occupy because of the very fact of increased competition. The ICC contends that such competition would, in fact, result in "unstable conditions" in the industry. ${ }^{139}$ "Unstable conditions" seems to refer to the repeated reductions of rates until they fall below the level of long run average costs resulting in the frequent entry and withdrawal of firms from the market. This result, according to the ICC, would seriously threaten stable and responsible service to shippers. ${ }^{140}$ Experience in industries comprised of a few producers of identical products has shown that component firms with high fixed costs to allocate do charge rates which fail to cover long run average costs in order to compete for additional business $;^{141}$ but since almost all trucking costs are variable, it is un-

Articles in Official Territory, 308 I.C.C. 439 (1959); for a discussion of the amendments, see Nelson, Ratemaking in Transportation-Congressional Intent, 1960 DukE L.J. 221 (1960).

Moreover, although the railroads were the primary advocates of regulation, it appears that value of service pricing by both trucks and railroads has been to the detriment of the latter. Meyers, Peck, Stenason \& Zwick, Conpetition in the Transportation Industries 181-84 (1959); see generally Nat. Transp. Policy Rep. 407-24 (1961). By matching the railroad rates on high value commodities, motor carriers have been able to divert a substantial amount of railroad traffic. LockLIN, Economics of Transportation 691 (3d ed. 1947). This has even included traffic for which the railroads are the lower cost carrier. Meyers, Peck, Stenason \& Zwick, supra at 188. For statistics concerning the large relative growth of trucking, see Williams, The Regulatron of RaIL-Motor Rate CoMPETrTION $4-7$ (1958). This diversion has been extremely harmful to the railroad industry because it is a declining cost industry and especially because the traffic diverted has been the high revenue traffic. United States Departarent of Coararerce, Federal Transportation Policy and Program 4 (1960). Recent governmental studies have concluded that both railroads and trucks should have a rate structure primarily determined by cost factors. Nat'l Transp. Policy Rep. $436-39$ (1961). United States Departanent of Commerce, Federai Transportation Policy and Programi 17-19 (1960).

139. Hearings on the Administration of the Motor Carrier Act by the Interstate Commerce Commission, As It Affects Small Truckers and Shippers Before the Senate Sclect Committee on Small Business, 84th Cong., 1st Sess. 327 (1955).

140. Id. at 330-337.

141. In industries with high overhead costs and a few sellers of identical products, firms often undersell each other in the hope of getting a larger share of the business. "This explains, for example, the railroad price wars of the past century. ... [E]ach of three or four trunk lines would intermittently undercut the existing rate schedules, until finally a disastrously low level of rates was reached. . . ." SAMrUELSON, Econonics 466 (3d ed. 1955). 
likely that today's trucking firms would, under more competitive conditions, charge rates which fail to cover the costs incurred in carrying the traffic. ${ }^{142}$ Furthermore the commission has adequate powers over the minimum rates of both contract and common carriers to prevent non-compensatory rates were the situation to occur. ${ }^{143}$ The assumption that a freer entry policy would lead to insufficient carrier revenues is based primarily on the pre-regulatory experience with motor carriers in the 1930's. However, conditions in the thirties provide a questionable basis for concluding that financial demoralization of all carriers would result from focusing on cost factors in entry proceedings. Because of the sharp decrease in industrial activity, most businesses had marked excess capacity and low revenues; in addition there was an absence of alternative employment and business opportunities during that period. Since the 1930's, the inexperienced owner-operator-an alleged cause of the chaotic conditions during the depression-has been eliminated by giving the ICC power to consider an applicant's fitness and financial status. ${ }^{144}$ Moreover, there is no evidence that the financial straits of carriers during the depression left the public without adequate transportation services. ${ }^{145}$ Indeed, the ease with which new carriers can enter the field, as a result of low threshold costs, ${ }^{146}$ belies the assumption that business failures, if they should result, would lead to serious deficiencies in service to shippers. ${ }^{147}$ Moreover, it may be argued that stability is needed for technological improvements, ${ }^{148}$ but it does not appear that technological advances are made by the carriers themselves in the trucking industry; research and development are apparently a function of truck manufacturers, and large amounts of capital are not needed to purchase improved equipment. ${ }^{149}$

Finally one may question the commission's basic assumption that the general shipping public is primarily dependent on the common carriage system for assured transportation. This view seems to confuse the motor common carrier with his present day counterpart, the railroads. Failure to realize the differences between the two has led to exaggerations about the significance of the motor common carrier. ${ }^{150}$ Railroads must haul virtually all traffic without discrimination over an extensive territory, whereas the motor common carrier

142. Because there are low threshold costs in a variable cost industry, there would seem to be no incentive for a carrier to engage in "destructive" rate cutting to eliminate competition-a trucker driven out of business can easily return or be replaced.

143. Pt. II, §§ 216, 218, 49 Stat. 558 (1935), 49 U.S.C. $\S \S 316,318$ (1958).

144. Pt. II, $\$ 207$ (a), 49 Stat. 551 (1935), 49 U.S.C. $\$ 307$ (a) (1958); Pt. II, $\$ 209$ (b), 49 Stat. 553 (1935), as amended, 49 U.S.C. $\$ 309$ (b) (1958).

145. See note 10 stipra.

146. See note 117 stipra.

147. The ICC might be thinking of the mere inconvenience of changing carriers frequently. This would seem to be a weak basis for their policy.

148. See, e.g., Schumpeter, Capitalisar, Soctalism and Demrocracy ch. 8 \& 9 (2d ed. 1947).

149. Williams, The Regulation of Rail-Motor Rate Conpetition 9 (1958).

150. E.g., Nat'l Transp. Policy Rep. 10 (1961). 
has been permitted to assume a far more limited obligation to the public. $\mathrm{He}$ may choose, on the basis of what he conceives to be a profitable operation, the commodities he will carry, the highways he will traverse, the origin, intermediate and destination points of the territory he will serve, the classes of shippers he will serve, and even the size of shipments he will carry. ${ }^{151}$ Thus, there are specialized motor common carriers whose operations, and actual obligations, are indistinguishable from those of the contract carrier. ${ }^{162}$ The common carrier, it is true, is supposedly required to serve all shippers alike. ${ }^{153}$ But even the ICC would not seem to take this obligation too seriously; it has increasingly encouraged common carriers to render individualized service to particular shippers which would seem to be inconsistent with the idea of equal treatment. ${ }^{154}$ And arbitrary discrimination in rates has never proved to be a problem, except for the discrimination legitimized in the value of service rate structure; there are a dearth of appeals for relief from discriminatory rate practices. ${ }^{155}$ This is not surprising since shippers have the advantage of many competing carriers. The ICC has claimed that the small shipper is particularly dependent on common carriage. It is true that the small shipper is presently served primarily by common carriers; but this is probably a result of the strict entry policy on contract carriers and a common carrier rate structure which has induced contract carriage to focus on volume shippers. ${ }^{150}$ There are instances, as the Reddish case demonstrates, where the contract carrier does offer a cheaper transportation service to small as well as large shippers by proposing a more efficient operation than that conducted by existing common carriers. If developments in transport have largely destroyed the monopoly position of common carriers and have made other transport more economical, the special importance attributed to the common carrier must be somewhat out of date. The protection of the common carrier under these conditions is likely to be in the interest of the protected class of carriers rather than of shippers or the public.

Although the economic structure of the trucking industry might well lead to the conclusion that no entry and rate regulation are needed, it is politically unrealistic to believe that regulation will be entirely abolished in the near future. These economic considerations at least indicate that the ICC should not disregard contract carrier rate and service advantages in order to effectu-

151. Hearings on the Administration of the Motor Carrier Act by the Interstate Commerce Commission, As It Affects Small Truckers and Shippers Before the Senate Selcct Committee on Small Business, 84th Cong., 1st Sess. 337-43 (1955).

152. See cases cited in note 42 supra.

153. 49 Stat. 558 (1935), 49 U.S.C. $\$ 316$ (d) (1958).

154. E.g., J-T Transp. Co. Extension, 79 M.C.C. 695 (1959).

155. T.I.M.E., Inc. v. United States, 359 U.S. $464,477-79$ and n.20 (1959). This case held that a shipper no longer has his common law remedy of reparation for unreasonable rates charged by a common motor carrier. The Court added that the abrogation of this remedy would not result in any hardship on shippers, since unreasonable rates (which would include discriminatory ones) rarely are charged by truckers. $I d$. at 477-79.

156. See note 129 supra and accompanying text. 
ate its unduly protective policy toward common carriers. In the case where not handling the traffic would have a present adverse effect on the economic efficiency of protestant common carriers, this factor must be balanced against the rate and service advantages offered by the contract carrier applicant. ${ }^{157}$ Also, the possible effect of this traffic upon the efficiency of the contract carrier applicant's other operations, if he has any, must be considered. ${ }^{158}$ Where no present economic injury appears, contract carrier rate and service advantages should ordinarily be decisive. Moreover, although limiting the applicant to designated shippers will reduce the possible competitive effect of a grant, such licensing would seem to be unduly restrictive, unless the commission is readily willing to grant additional authority to the contract carrier if he loses any of these designated shippers.

157. In determining an adverse effect on protesting common carriers, the commission must, of course, also consider whether the goods in question will move by common carriage if the application is refused. The shipper may decide to institute or continue his own trucking services if contract carriage is denied to him.

158. This must be the meaning of "adverse effect on the applicant" intended by the statute; otherwise, one is left with considering only such factors as the applicant's desire to conduct tranportation operations or his ability to make profits-subjects obviously not relevant to transportation decisions. The commission seems to have recognized this definition of "adverse effect" in Reddish. 81 M.C.C. 35, 41-42 (1960). 